\title{
A nagy imitátor
}

\author{
Murányi Mihály dr. - Kiss Zoltán dr. - Farkas Antal dr. - Flaskó Tibor dr.
}

Debreceni Egyetem, Klinikai Központ, Urológiai Klinika, Debrecen

\begin{abstract}
A szerzők két vesetuberculosis esetét ismertetik, amelyekben a tényleges diagnózis késett az aspecifikus vagy más betegséget utánzó tünetek miatt. Az első beteget bal oldali derékfájdalom és láz miatt vizsgálták. Komputertomográfia bal oldali zsugorvesét; retrográd pielográfia kaliberingadozó uretert, a vesében margarétajelet igazolt. A vizelettenyésztés Mycobacterium tuberculosist mutatott ki. Az antituberculoticus kezelés indítása után két hónappal a vesét eltávolították. A második beteget antibiotikum-kezelésre nem múló láz miatt vizsgálták. Az ultrahangvizsgálaton bal oldali pyelectasia, pyelonkő és perirenalis abscessus ábrázolódott. A vesét deviálták, a tályogot pungálták és drenálták. A kiürülő gennyből Proteus morganii tenyészett ki. Antibiotikum hatására láza és panaszai megszüntek. Két hónappal később perzisztáló pyelonephritis miatt a dupla J-katétert kicserélték. Egy héttel később intravénás antibiotikum-kezelésre sem szúnő láz miatt végzett komputertomográfia a bal vese tályogos átalakulását mutatta ki, ezért nephrectomiát végeztek. A szövettani vizsgálat igazolta a vesetuberculosist. A két eset kapcsán a szerzők összefoglalják a vesetuberculosis diagnosztikáját és terápiáját. Orv. Hetil., 2016, 157(9), 350-356.
\end{abstract}

Kulcsszavak: tuberculosis, urogenitalis tuberculosis, vesetuberculosis, nephrectomia

\section{The Great Imitator}

\section{Case report}

Authors present two patients suffering from renal tuberculosis, which caused differential diagnostic problems. The first patient was examined because of fever and left flank pain. Computed tomography revealed renal shrinkage on the left side. Retrograde pyelography demonstrated ureteric stricture and dilated calices. Urine culture showed $M y$ cobacterium tuberculosis. Two months after initiation of the antituberculotic therapy nephrectomy was performed. The second patient was referred to the department because of fever after unsuccessful antibiotic treatment. Ultrasound examination showed a staghorn stone, dilated renal pelvis and perirenal abscess on the left side. Double J catheter insertion and percutaneous puncture of the abscess were performed. Culture of the pus aspirated proved Proteus morganii. Fever and complaints of the patient relieved after antibiotic treatment. Two months later double J catheter was changed because of persistent pyelonephritis. One week later the patient returned to the hospital with fever, which could not be reduced with intravenous antibiotics. Computed tomography showed purulent fluid in the left kidney, and nephrectomy was performed. Histology revealed renal tuberculosis. The authors summarize the diagnosis and treatment of renal tuberculosis on the basis of these two cases.

Keywords: tuberculosis, urogenital tuberculosis, renal tuberculosis, nephrectomy

Murányi M., Kiss, Z., Farkas, A., Flaskó, T. [The Great Imitator. Case report]. Orv. Hetil., 2016, 157(9), 350-356.

(Beérkezett: 2016. január 3.; elfogadva: 2016. január 21.)

\section{Rövidítések}

BCG = bacillus Calmette-Guérin; CRP = C-reaktív protein; $\mathrm{CT}=$ komputertomográfia; DJ-katéter = dupla J-katéter; DNS = dezoxiribonukleinsav; FVS = fehérvérsejtszám; GFR = glomerularis filtrációs ráta; $\mathrm{HE}=$ hematoxilin-eozin; HIV = human immunodeficiency virus; INH = izonikotinsav-hidrazid; LESS = laparoendoscopic single site surgery; MR = mágneses rezonanciás képalkotás; PCR = polymerase chain reaction; SLE = szisztémás lupus erythematosus; WHO = World Health Organization
A nagy imitátor jelzővel azokat a megbetegedéseket jellemezzük, amelyek az emberi szervezet bármely szervrendszerét érinthetik, tünetrendszerük változatos, sokszor differenciáldiagnosztikai problémát jelentenek. Számos fertőző és nem fertőző megbetegedést neveztek már nagy imitátornak, többek között a syphilist, Lymekórt, HIV-fertőzést, SLE-t. Nem kétséges, hogy a tüdőt, pleurát, csontot, bőrt, szemet, központi idegrendszert, hasüregi szerveket - a legkülönfélébb tünetekkel kísérve 


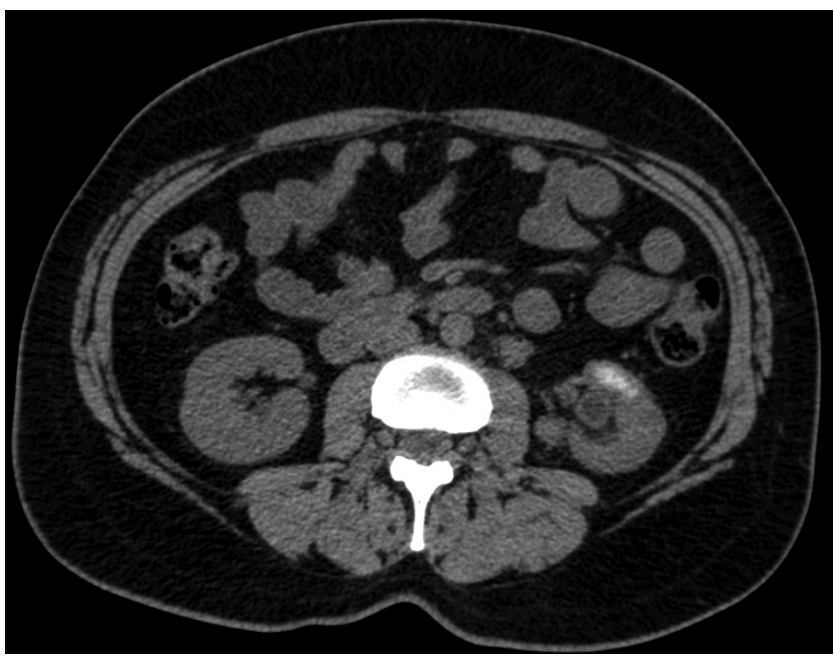

1. ábra

CT-vizsgálat natív axiális felvétele az első betegrôl; a bal vese mediocranialis részén meszesedés ábrázolódik

- megbetegíteni képes tuberculosisra (tbc) is illik a meghatározás. Az urogenitalis rendszert is érintheti a tbc, sokszor más betegség tüneteit utánozva.

Két vesetuberculosisban szenvedő betegünk esetét ismertetjük. Mindkettejük végleges diagnózisa késve, a tünetek jelentkezése után hónapokkal született meg, köszönhetően az aspecifikus panaszoknak, illetve más betegséget utánzó tüneteknek.

\section{Esetismertetés}

\section{Elsó eset}

Az 51 éves nő két éve történt bal oldali sorozat-bordatörése óta küzdött bal oldali derékfájással. A panasz miatt urológiai vizsgálat nem történt, hiszen a beteg azt a korábbi bordatörés következményének vélte. Pár hónapja kezdődő tisztázatlan eredetű visszatérő láz, pyuria miatt többször kapott antibiotikum-kezelést - eredménytelenül. Ezt követően más intézetben ultrahang-, majd CTvizsgálattal (1. ábra) bal oldali zsugorvese, pyelectasia igazolódott, emiatt küldték klinikánkra. Érkezésekor láztalan volt, vizelési panaszai nem voltak. Laboratóriumi vizsgálatok során enyhén emelkedett CRP-n (17,6 $\mathrm{mg} / \mathrm{L}$ - normális érték: $<4,6 \mathrm{mg} / \mathrm{L})$ és csökkent GFRen $\left(79 \mathrm{~mL} / \mathrm{p} / 1,73 \mathrm{~m}^{2}-\right.$ normális érték: $>90 \mathrm{~mL} / \mathrm{p} / 1,73$ $\mathrm{m}^{2}$ ) kívül más eltérés nem igazolódott. A vizeletüledék mikroszkópos vizsgálatakor nagy látóterenként 100-120 fehérvérsejt volt látható. Ultrahangvizsgálata a bal vesében üregrendszeri tágulatot igazolt. Retrográd ureteropielográfiát végeztünk, a bal ureterszájadék felhúzott, környezete hyperaemiás, az ureter teljes hosszán kaliberingadozó volt. A vesében margarétajelet figyeltünk meg: a pyelon és a kehelyszárak beszúkültek, a kehelyvégek kifejezetten tágak voltak. A veséből sűrü, fehér gennyes vizelet ürült. Vizelet-mintavétel után a vesébe dupla J-katétert vezettünk fel. A tünetek és radiológiai jelek alapján vesetuberculosis gyanúja merült fel. A beteggel történő ismételt beszélgetés során kiderült, hogy tíz éve települt át Magyarországra Ukrajnából. A korábbi lakhelyén a szomszédai közül többen voltak tbc-sek. A ZiehlNeelsen-festékkel kezelt vizeletminta mikroszkópos vizsgálata saválló baktériumot igazolt; a tenyésztés során Mycobacterium tuberculosis tenyészett ki. A hármas kombinációban (rifampicin, isoniazid, ethambutol) adott gátlószeres kezelés indítása után két hónappal nephrectomiát végeztünk (2. ábra). A szövettani vizsgálat a veseparenchyma pusztulását okozó vesetuberculosist igazolt, amely granuloma-, abscessus- és cavernaképződéssel párosult. A granulomák centrumában sajtos necrosis volt látható, Ziehl-Neelsen-festéssel saválló baktériumok igazolódtak. A gátlószeres kezelés komplettálása után öt évvel a beteg tünetmentes.

\section{Második eset}

Az 57 éves nő két hete tartó antibiotikum-kezelésre nem szűnő láz, vizeletcsípés, húgycsőfájdalom miatt érkezett ambulanciánkra. Fizikális vizsgálata során a bal vesetájék kifejezetten nyomásérzékeny volt, laboratóriumi vizsgálata emelkedett gyulladásos paramétereket igazolt (FVS: 12,3 giga/L - normális érték: 4,5-10,8 giga/L, CRP: $168 \mathrm{mg} / \mathrm{L}$ - normális érték: <4,6 mg/L), vizeletüledék vizsgálata bacteriuriát és pyuriát mutatott ki. Ultrahangvizsgálaton a bal vese parenchymája duzzadt $(20 \mathrm{~mm})$, echószegény volt, a pyelonban $3 \mathrm{~cm}$-es kő, a vese alatt $8 \mathrm{~cm}$-es abscessus ábrázolódott. A kő a felső vesekehely tágulatát okozta, ezért ide dupla J-katétert vezettünk (3. ábra), a tályogot pedig percutan pungáltuk és drenáltuk. A tályogpunctio során ürülő sűrü, világoszöld gennyből multirezisztens Proteus morganii tenyészett ki. Mindezek alapján egy vesekő talaján kialakult Proteus-

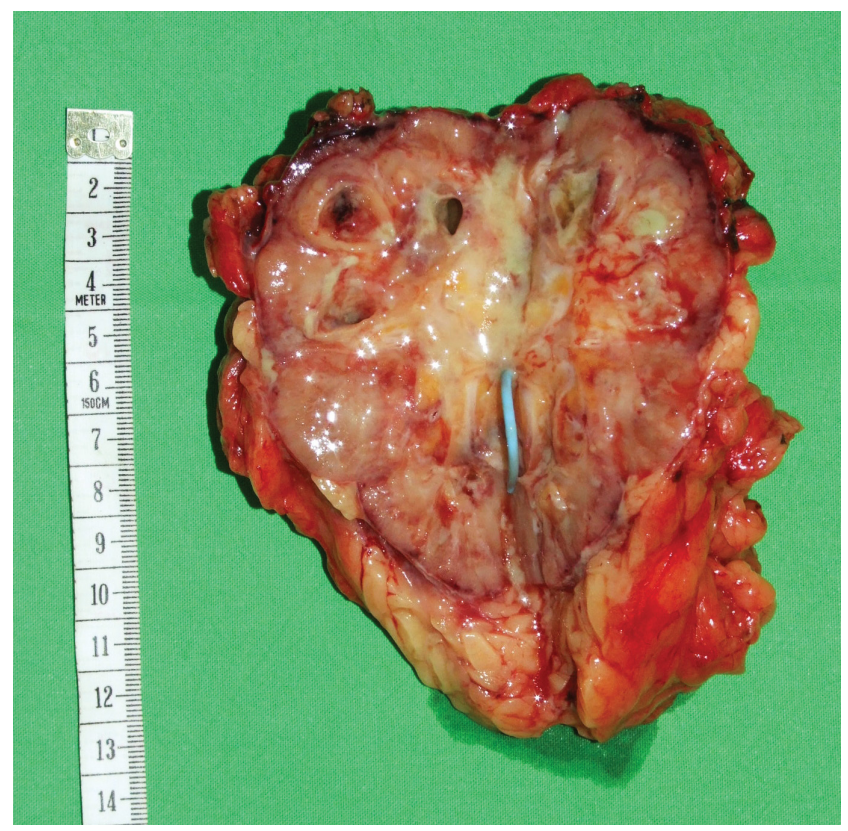

\begin{tabular}{l|l} 
2. ábra & Az első betegból eltávolított bal vese
\end{tabular} 


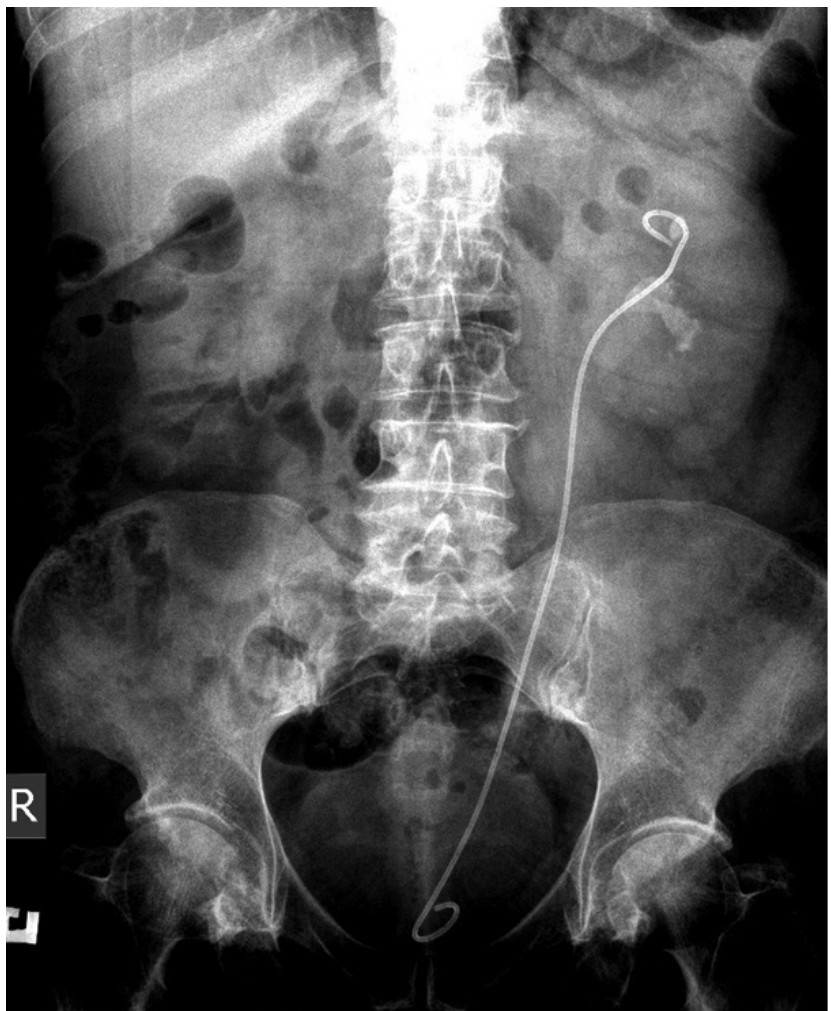

3. ábra

Natív vese-röntgenfelvétel a második betegről; a bal oldalon pyelectasiát okozó pyelonkő és az emiatt felhelyezett DJ-katéter ábrázolódik

fertőzés okozta occlusiv pyelonephritis és következményes perirenalis tályog képe bontakozott ki. Kombinált antibiotikum-kezelés hatására láza megszűnt, panaszmentessé vált, drénje eltávolítása után további célzott antibiotikum-javaslattal hazabocsátottuk. Két hónappal késóbb a bal vesében lévő kő percutan eltávolítását terveztük, ám a vese parenchymája továbbra is vaskos (20$22 \mathrm{~mm}$ ) és echószegény volt, ezért a mütétet elhalasz-

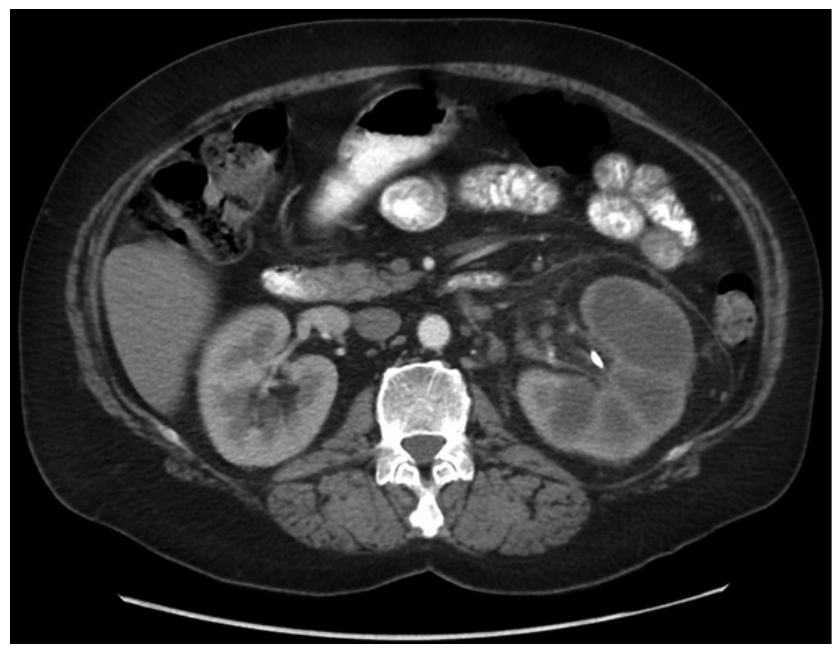

4. ábra

CT-vizsgálat artériás fázisú axiális felvétele a második betegről; a bal vese nem választ ki, parenchymája megvastagodott, hypodens tottuk. DJ-katéterét kicseréltük, a korábbi tenyésztés eredménye alapján ismételt antibiotikum-kezelést indítottunk. A frissen végzett vizelettenyésztés kórokozót nem mutatott ki. A dupla J-katéter cseréje után egy héttel magas láz miatt vettük fel klinikánkra. Vizelettenyésztése kórokozót ismételten nem igazolt. Láza kombinált intravénás antibiotikum-kezelésre nem szűnt meg. Sürgôs CT-vizsgálat (4. ábra) során a bal vese multiplex tályogos átalakulása ábrázolódott, ezért bal oldali nephrectomiát végeztünk (5. ábra). A szövettani vizsgálat mutatta ki a vesetuberculosist. A vesében összefolyó jelleggel sajtos necroticus területek voltak láthatók, a sajtos massza széli részein saválló pálcák igazolódtak (6., 7. ábra). Féléves antituberculoticus terápia után három évvel a beteg jól van.

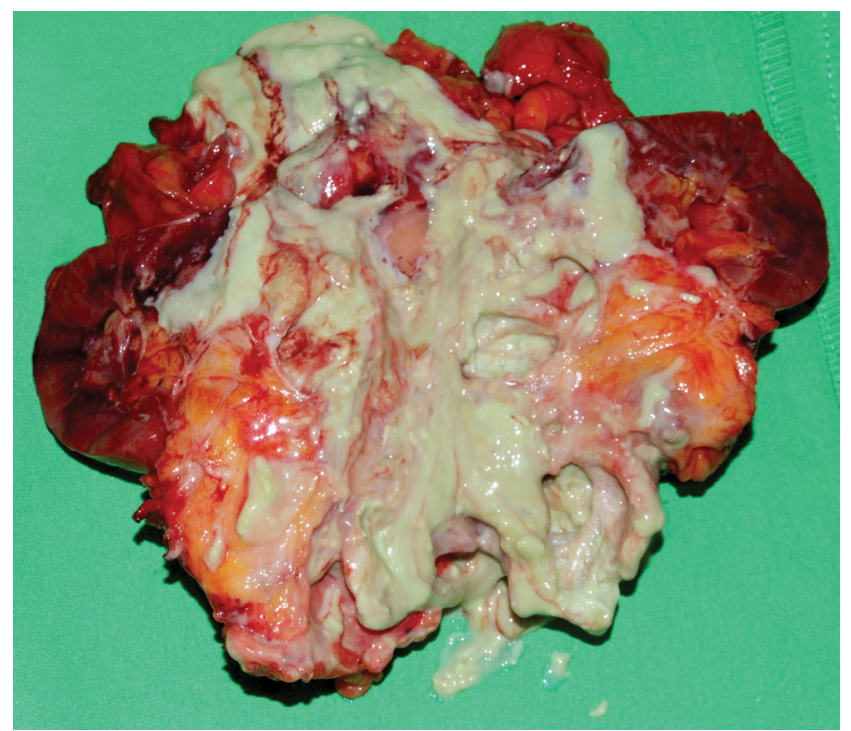

5. ábra | A második betegből eltávolított bal vese

\section{Megbeszélés}

A tuberculosis az emberiséget évezredek óta kísérő, tizedelő kór. Jelentősége mindmáig nem csökkent, hiszen a világ lakosságának egyharmada jelenleg is tuberculosisbaktériummal fertőzött [1]. A tbc több évezredes történetét bizonyítják a 4000-5000 éves emberi csontmaradványokban kimutatott Mycobacteriumok [2]. Európában a XIX. században és a XX. század elején a vezető halálokok közé tartozott a gümőkór. Ebben az időszakban az emberek tudatában a halál szinonimájaként szerepelt a tuberculosis, ami a hatékony diagnosztika és kezelés híján talán nem is volt túlzás. A megbetegedés elleni hatékony küzdelem 1882-ben vette kezdetét, amikor Robert Koch felfedezte a Mycobacterium tuberculosis baktériumot. Az előrelépés további állomásai a röntgen-képalkotás felfedezése és bevezetése a klinikai gyakorlatba, a BCG védőoltás kifejlesztése és a hatékony antituberkulotikumok - elsőként 1944-ben a streptomycin - felfede- 

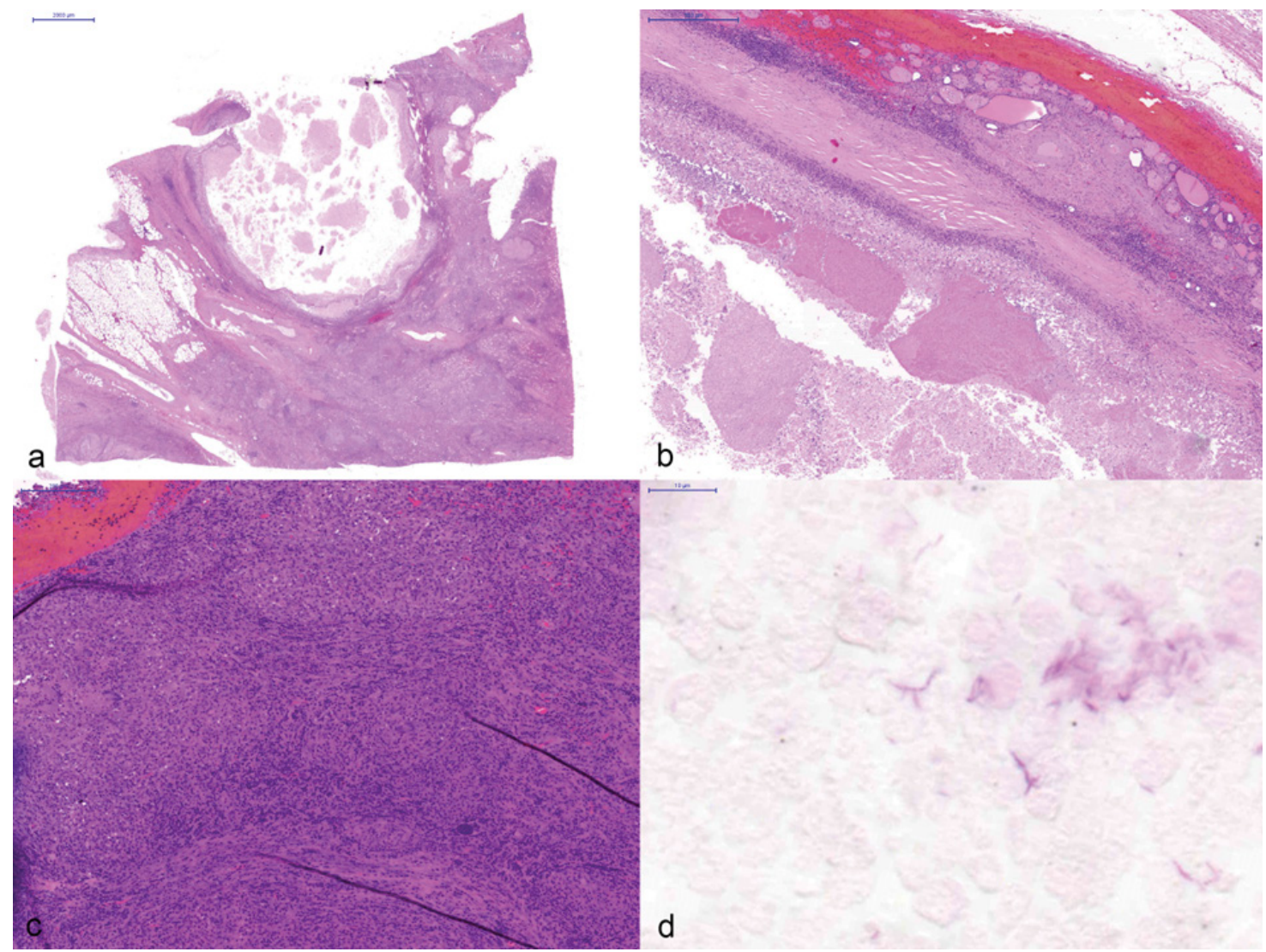

6. ábra

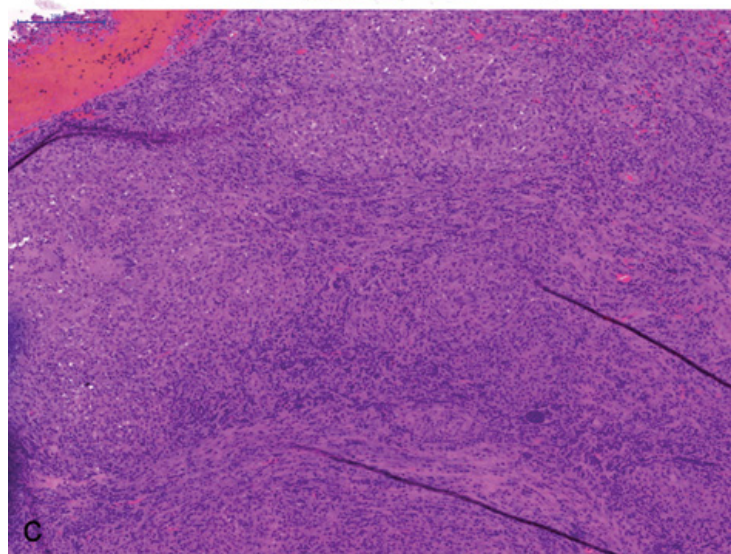

A második betegból eltávolított vese szövettani vizsgálata során készült mikroszkópos képek: a) hematoxilin-eozin (HE) festett minta, átnézeti kép a veseparenchymában elhelyezkedő tályogról; b) a tályog fala (HE); c) granuloma nagy nagyítású képe gyulladásos és epitheloid sejtekkel (HE); d) Ziehl-Neelsen-festéssel készült nagy nagyítású képen vörösen festődő saválló pálcák

zése volt. A tuberculosis ennek köszönhetően gyógyítható betegséggé vált. A populációszintû szűrés megszervezésének, az életkörülmények javulásának és az évtizedek óta tartó békének köszönhetően mára ÉszakAmerikában, Európában és ezen belül Magyarországon is sikerült jelentősen visszaszorítani a tbc előfordulását [2]. Hazánkban 2014-ben a tuberculosis incidenciája

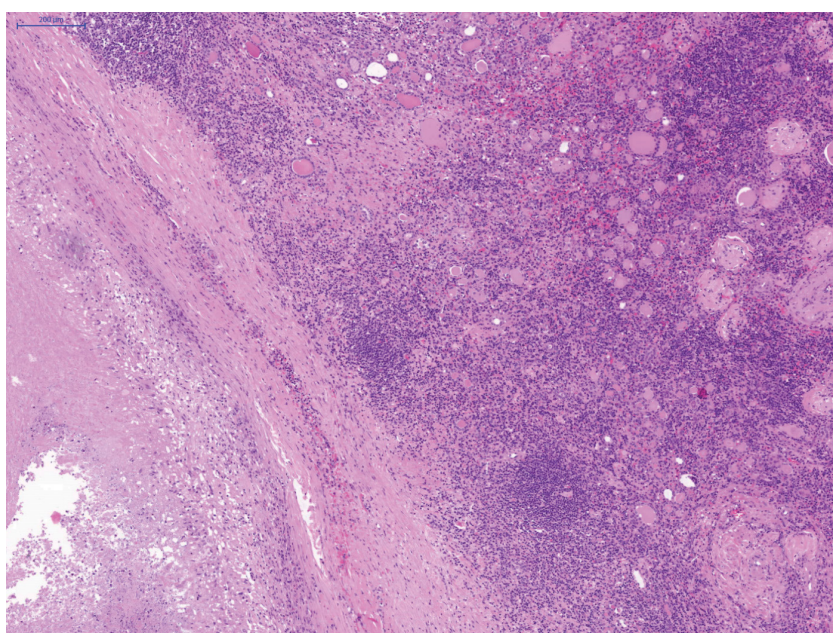

7. ábra

A második beteg veséjéból hematoxilin-eozin festéssel készült metszeten tályogfal mellett szklerotizált glomerulusok és gyulladásos sejtek
9,1/100 000 volt. A WHO kritériumai alapján jelenleg az alacsony fertőzöttségű országok közé tartozunk. Az országban a tuberculosis előfordulása nem egyenletes, Szabolcs-Szatmár-Bereg megyében, Hajdú-Bihar megyében, Borsod-Abaúj-Zemplén megyében az incidencia az országos átlagnál magasabb [3].

$\mathrm{Az}$ extrapulmonalis tuberculosis előfordulása napjainkban ritka. Gyakoriság tekintetében az extrapulmonalis lokalizáción belül az urogenitalis tuberculosis a 3 . helyet foglalja el a pleuritis tuberculosa és a nyirokcsomó-tuberculosis után [2]. Magyarországon 2014-ben a húgyivari szerveket érintő megbetegedés incidenciája 0,1/100 000 volt [3]. A kedvező adatok azonban a gümőkór iránti éberséget nem csillapíthatják, hiszen a szervezet védekezőképességét rontó tényezők megléte esetén a tuberculosissal továbbra is számolni kell.

Világszerte a HIV-fertőzés a tuberculosis egyik legfontosabb rizikófaktora. Szerencsére Magyarországon a HIV-pozitív tbc-s betegek száma elenyésző [3]. A HIVfertőzés mellett a fejletlen egészségügyi rendszer, az állandó háborúk okozta éhezés miatt a világ számos részén, elsősorban Délkelet-Ázsiában, Csendes-Óceániában és Afrikában a tuberculosis jelenleg is égető egészségügyi probléma, ezeken a területeken jelenleg is igen magas a tbc-incidencia és -mortalitás [2]. A helyzetet súlyosbítja a multirezisztens, valamint az extenzíven rezisztens tör- 
zsek megjelenése és terjedése. Némi optimizmusra adhat azonban okot, hogy a WHO adatai alapján az utóbbi másfél évtizedben a világon a tbc összincidenciája és mortalitása jelentősen csökkent [4].

Tuberculosist a Mycobacterium tuberculosis komplexbe tartozó kórokozók - Mycobacterium tuberculosis, M. bovis, M. africanum, M. canetti, M. microti - okozhatnak [5]. A megbetegedések többségét a $M$. tuberculosis okozza, amely obligát patogénnek tekinthető. A baktérium felépítése jelentősen eltér más baktériumokéhoz képest. Gram szerint nem festődik, sejtfala nagy mennyiségű lipidet tartalmaz [5]. Többek közt ez magyarázza sajátos festődési (saválló) tulajdonságát és az emberi szervezettel való speciális interakcióját. A baktérium lassan szaporodik és a külső behatásokkal szemben igen ellenálló. A kórokozó átvitele leggyakrabban cseppfertőzéssel történik, a fertőzés első állomása ezért többnyire a tüdő. A megbetegedés lefolyását a szervezetbe jutó kórokozók mennyisége, virulenciája mellett a szervezet védekezőképessége határozza meg [6]. Egészségesekben a szervezet képes lehet a kórokozó teljes eradikálására. Az esetek többségében azonban lezajlik egy akár észrevétlen primer fertőzés, a specifikus immunválasz legyőzi a baktériumot, de kis számban dormáns formában a baktérium jelen lesz évekig, évtizedekig. Gyenge immunválasz esetén a primer tbc tüneteinek széles skálájával találkozhatunk, legsúlyosabb esetben miliaris tbc alakul ki. A dormáns, alvó állapotban lévő baktériumok időskorban, a védekezőképesség csökkenése (alultápláltság, senyvesztő betegségek, HIV-fertőzés, immunszuppresszió) esetén visszaszerezhetik megbetegítő képességüket, amely postprimer tuberculosis képében jelenik meg [5]. A postprimer tbc a fenti reaktivációs mechanizmus mellett 3040\%-ban reinfekció következtében alakul ki [2].

$\mathrm{Az}$ urogenitalis tbc jellemzően a betegség postprimer stádiumában jelenik meg, a primer infekció helyéról haematogen módon történik a fertőzés, általában még a primer infekció idején [6]. Elsőként a vese, mellékhere, prosztata fertőződik meg a véráram útján, majd innen canalicularisan, lymphogen úton vagy direkten terjedhet az ureterre, húgyhólyagra, herére, vesicula seminalisra, ritkán a hímvesszőre, húgycsőre [1].

A leggyakrabban érintett urogenitalis szerv a vese. A folyamat általában egyoldali. A vesében a pulmonalis tbc-hez hasonló szöveti reakció (IV. típusú túlérzékenységi reakció) alakul ki. A Mycobacterium elleni immunválasz nemcsak a kórokozót, hanem a vese szöveteit is károsítja; granulomák, cavernák, sajtos necrosis alakul ki, amely később hegesedik, elmeszesedik. A folyamat végül a vese teljes pusztulásához, autonephrectomiához vezethet, emellett hypertonia is kialakulhat. A tuberculosis a kehelyszárak, pyelon, pyeloureteralis határ hegesedését, szúküuletét okozhatja; később a vizeletelvezetô rendszerben lefelé haladva ureterszúküulet, zsugorhólyag alakulhat ki [l].

A vesetuberculosis diagnosztikája nehéz, mivel a panaszok, tünetek nem specifikusak és igen változatosak le- hetnek, ezek alapján sokszor más betegség képe bontakozik ki. A nemzetközi irodalom beszámol komplikált vesecysta [7], kétoldali hydronephrosis hátterében igazolódott vesetuberculosisról [8]. Klinikai kép és radiológiai vizsgálatok alapján vesetumornak [9] vagy xanthogranulomatosus pyelonephritisnek [10] imponáló elváltozást is okozhat tbc. Natív vese-röntgenfelvételen a tuberculosis okozta calcificatio vesekő képében jelenhet meg, ezzel okozva differenciáldiagnosztikai nehézséget [11]. Emellett beszámoltak renovascularis hypertensio képében megjelenő tbc-s folyamatról is [12]. A tuberculosis diagnózisa mindezek miatt gyakran késik vagy nem is történik meg [1].

$\mathrm{Az}$ anamnézis felvétele során számba kell venni a tuberculosis rizikóját növelő tényezőket: alkoholfüggőséget, drogfüggőséget, diabetes mellitust, daganatos megbetegedéseket, alultápláltságot, immunszuppresszióval járó állapotokat, korábbi primer tuberculosist [1]. Mivel a hajléktalanoknál; családban, lakóközösségben előforduló tuberculosis esetén; magas tbc-incidenciával rendelkező országokból (Románia, Ukrajna, Oroszország) történő bevándorlóknál és egészségügyi dolgozóknál magasabb a betegség előfordulása $[2,3]$, ezért ezeket a körülményeket is tisztázni kell.

Általános tünetként jelentkezhet hőemelkedés, láz, éjszakai izzadás, fáradékonyság, étvágytalanság, fogyás, amely sokszor hosszú időn keresztül fennáll, hagyományos kezelésekre nem reagál, eredete tisztázatlan marad. $\mathrm{Az}$ urogenitalis szervek érintettségére hívja fel a figyelmet a derékfájás, dysuria, pollakiuria. A veséból sajtos necroticus massza, vesepapilla-necrosis darabkái ürülhetnek, amely vesekólikát is okozhat [13].

A vizeletüledék-vizsgálat során gyakran találkozunk pyuriával, haematuriával, proteinuriával, ugyanakkor hagyományos tenyésztési eljárásokkal kórokozó nem mutatható ki (steril pyuria) [6]. Fontos megjegyezni azonban, hogy az esetek 20\%-ában tuberculosis mellett más kórokozók is társulnak a fertőzéshez [14].

A tuberculosis igazolása a kórokozó kimutatásán alapszik. Ennek klasszikus és legmegbízhatóbb módja a mikrobiológiai tenyésztés [15]. Minden esetben törekedni kell a baktérium kitenyésztésére, hiszen a megbetegedés igazolása mellett ez rezisztenciavizsgálatra is alkalmas. A Mycobacterium tuberculosis hagyományos táptalajokon nem tenyészthető, ezért a kimutatáshoz a 4-6 hetet igénybe vevő tojásalapú Löwenstein-Jensen-, az agaralapú Middlebrook-táptalaj vagy a gyorsabb eredményhez (2-3 hét) vezető folyékony táptalajok (például BACTEC) alkalmazhatók [5]. A Mycobacterium tuberculosis igazolása után a rezisztenciameghatározás további 3-6 hetet is igénybe vehet [2]. A minta lehet vizelet, sebváladék, tályogváladék, vér vagy bioptátum. Mivel a vizelet kevés kórokozót tartalmaz, korrekt diagnózist sorozattenyésztéssel (3-5 alkalom) érhetünk el, egymás utáni napokon vett reggeli első vizeletminták levételével $[1,6]$. A megfelelő mikrobiológiai diagnózis feltétele a kellő mennyiségű (>40 ml) spontán ürített középsugaras vagy katéte- 
res (nem gyưjtött, nem vizeletgyưjtő zsákból származó) vizelet. Fontos tudni azonban, hogy a mintavétel és a tenyésztés szabályainak legkörültekintőbb alkalmazása mellett sem 100\%-os a tenyésztés érzékenysége. A tenyésztés nemcsak a diagnosztika elengedhetetlen része, hanem a kezelés hatásosságának monitorozásához is szükséges [2].

A baktérium DNS-ének PCR-technikával történő direkt kimutatásával gyors diagnózishoz juthatunk. A módszer a mintában kis számban jelen lévő Mycobacterium kimutatására is alkalmas [2]. A módszer szenzitivitása és specificitása magas, a vizsgálathoz itt is többszöri mintavétel szükséges [1]. Antibiotikum-rezisztenciáért felelős mutációk kimutatására is rendelkezünk gyors molekuláris teszttel [16].

A Ziehl-Neelsen-festést követő mikroszkópos vizsgálat a leggyorsabb, legegyszerúbb és legolcsóbb mycobacteriológiai vizsgálat, azonban érzékenysége alacsony. Nagy problémát jelent, sokszor lehetetlen a vizeletben kis számban jelen lévő baktériumok kimutatása [6]. A vizsgálat nem tud ugyanakkor különbséget tenni az élő és elpusztult baktériumok között, emellett a $M y c o-$ bacterium tuberculosis mellett számos más, tuberculosist nem okozó Mycobacterium és több rokon genusokba tartozó baktérium (Nocardia, Rhodococcus, Actinomyces, Corynebacterium, Legionella) is pozitív eredményt adhat [2].

A tuberkulin-bőrteszt szintén gyors, 2-3 nap alatt eredményt adó indirekt, a specifikus immunválaszt vizsgáló szűrő és diagnosztikai módszer, azonban szenzitivitása és specificitása alacsony. Álpozitív eredményhez vezethet a hazánkban is alkalmazott BCG-vakcináció [15] és a hólyagtumor miatt végzett BCG-instillatio [1]. Tuberkulinteszttel negatív betegek esetén végzett BCG-hólyaginstillatio után Bilen és mtsai 68\%-ban mutattak ki tuberkulinpozitivitást [17]. A bőrteszt a korábban lezajlott és jelenleg is aktív fertózés között nem tud egyértelműen különbséget tenni. A bőrteszt további hátránya, hogy gyenge immunválasz esetén, fulmináns esetekben álnegatív lehet az eredmény [5]. A módszer korlátai ellenére mégis a diagnosztikai repertoár értékes tagja, a látens fertőzések kimutatására is alkalmas [2].

A hagyományos bőrtesztekhez képes elörelépést jelentett az indirekt - tbc elleni sejtes immunválaszt vizsgáló - interferon-gamma-tesztek (például Quantiferon tesztek) bevezetése. A tuberkulintesztnél magasabb szenzitivitással és specificitással rendelkeznek, a BCG és a nem tuberculosist okozó Mycobacteriumok okozta álpozitivitás aránya kisebb [2].

A vesetuberculosis okozta szöveti elváltozások sok esetben vezetnek radiológiai eltérésekhez. Ezen jelek egyike sem pathognomicus, ám - különösen több radiológiai jel jelenléte esetén - felvethetik a tuberculosis gyanúját [1]. Natív vese-röntgenvizsgálat hyperdens gócként ábrázolja a vesében lévő calcificatiót. Kiválasztásos urográfia, retrográd vagy antegrád pielográfia során izolált kehelyszárszúkület és következményes kehelytágulat, teljes kehelyszár-elzáródás okozta hiányzó - amputált kehely; pyeloureteralis határ szúkület; margarétajel (pyelon- és kehelyszár-szúkület kehelytágulattal) ábrázolódhat. Tbc-re jellegzetes lehet a kirágott kontúrú veseüregrendszer és az üregrendszerrel kommunikáló caverna. A retrográd és antegrád pielográfia előnye, hogy a beavatkozással egyidejűleg vizeletminta nyerhető és szükség esetén a vizeletdeviatio (dupla J-katéter felvezetése vagy percutan nephrostoma behelyezése) is kivitelezhető. Az ultrahang- és CT-vizsgálatnak a kehelytágulat, parenchymacalcificatio, zsugorvese kimutatása mellett a differenciáldiagnosztikában is szerepe van, CTvizsgálattal kimutathatók az extrarenalis tbc-s gócok is. Vesetuberculosis esetén sem szabad megfeledkezni a mellkas röntgenvizsgálatáról, hiszen az esetek felében ábrázolódik specifikus folyamat a tüdőben [1, 2].

A vesetuberculosis kezelésének alapja - hasonlóan a pulmonalis tbc-hez - a gyógyszeres, több antituberculotikummal végzett hosszú távú kezelés $[1,5,6]$. A kombinált kezelés szükségességének az az oka, hogy a $M y c o^{-}$ bacterium tuberculosis a fertőzés során a vese több kompartmentjében (extracelluláris térben, intracelluláris térben, sajtos necroticus masszában, cavernákban) is jelen van. Ezen kompartmentek mikrokörnyezete, $\mathrm{pH}$-ja jelentősen eltér, az egyes antituberkulotikumok hatékonysága emiatt a kompartmentekben más és más. A baktérium eradikálásához ezért az összes kompartmentet lefedő kombinált gyógyszeradagolásra van szükség [1]. Emellett a rezisztens kórokozók szelektálódásának megakadályozása miatt is indokolt több kemoterapeutikum adása [5].

A hosszú távú kezelést az indokolja, hogy a kórokozó igen ellenálló. Bár a kezelés megindítása után a nagy számban jelen lévő aktív baktériumok gyorsan pusztulnak, a szemidormáns, dormáns baktériumok elpusztításához hosszú idő kell. Komplikáló tényezők hiányában a kezelés 6 hónapig szükséges. Az első 2 hónap (iniciális fázis) során 3-4 kemoterápiás szer (rifampicin, INH, pyrazinamid, ethambutol) kombinációját adjuk az aktívan metabolizáló baktériumok elpusztításához, majd 4 hónapos fenntartó kezelés (kontinuációs fázis) következik 2 antituberkulotikummal (rifmampicin, INH) a lassan metabolizáló kórokozók ellen [15]. A fél éves kezelés meghosszabbítása 9 vagy 12 hónapra csak komplikáló tényezők esetén szükséges (immunszuppresszió, rekurrens fertőzés, HIV-fertőzés). Multidrog-rezisztencia esetén a kezelés legalább 18 hónapig tart [6].

A kezelés során az esetek mintegy felében sebészi beavatkozás is szükségessé válik [1]. A vesetuberculosis miatt végzett mútétek spektruma széles, a DJ-katéterbehelyezéstől az infundibuloplasticán keresztül a nephrectomiáig terjed, függően a vese állapotától [18]. A mútétet a kemoterápiás kezelés megkezdése után kell elvégezni, de még az extenzív gyógyszeradagolás első 2 hónapja alatt [6]. Ez alól kivételt képeznek a sürgős vizeletdeviációt célzó beavatkozások - dupla J-katéter behelyezése vagy percutan nephrostomia. A mütétes keze- 
lésnél a nefronkímélő szemléletet kell alkalmazni. Pyeloureteralis szúkuulet esetén lehetőség van a pyelonplasztikára, a vesében fokálisan jelen lévő destrukció esetén partialis nephrectomia javasolt. Nephrectomia a vese teljes pusztulása esetén indikált. Az eltávolított szövet sok esetben tartalmaz élő Mycobacteriumot [6], amely aláhúzza a hosszú távú kemoterápiás kezelés fontosságát. Emellett megerősíti azt az alapelvet, hogy mútét esetén a retroperitonealis behatolás a választandó módszer, elkerülendő a kórokozók hasüregbe kerülését.

A mútétek elvégezhetők nyíltan, gyakorlott operatőr esetén laparoszkóposan, retroperitoneoscoposan vagy akár LESS-technikával is [19, 20]. A gyógyszeres kezelés pontosan lefektetett szigorú szabályaitól eltérően a mútétes kezelés maximálisan individualizált. Ezt az indokolja, hogy a vesetuberculosisban a tünetrendszer változatossága mellett a szöveti destrukció kiterjedése, mintázata is változatos. Ezért a beteg állapotának legmegfelelőbb sebészi kezelést kell alkalmaznunk [1].

\section{Következtetések}

Bár a világ számos részén a tuberculosis jelentős egészségügyi probléma, hazánkban az epidemiológiai adatok kedvezőek. A gümőkór iránti éberség azonban nem csökkenhet, különösen a szervezet védekezőképességét rontó tényezők megléte esetén. A Mycobacterium tuberculosis számos tulajdonságban eltér más baktériumoktól, az ellene kialakuló immunválasz speciális, a betegség tünetrendszere változatos, a baktérium hagyományos táptalajon nem tenyészik. A kórisme felállítása ezért nehézkes, sokszor késik. A diagnózis kulcsa a tbc-re jellemző tünetek, jelek észben tartása és gyanú esetén a baktérium kimutatására célzott vizsgálatok végzése.

Anyagi támogatás: A szerzők anyagi támogatásban nem részesültek.

Szerzői munkamegosztás: M. M.: A kézirat megírása, adatgyüjtés, irodalomkutatás. K. Z., F. A.: Adatgyújtés, irodalomkutatás, a kézirat kiegészítése. F. T.: Témaválasztás, a kézirat kritikai észrevételezése, javítása, kiegészítése. A kézirat végleges változatát valamennyi szerző elolvasta és jóváhagyta.

Érdekeltségek: A szerzőknek nincsenek érdekeltségeik.

\section{Irodalom}

[1] Ghoneim, I. A., Rabets, J. C., Mawhorter, S. D.: Tuberculosis and other opportunistic infections of the genitourinary system. In.: Wein, A. J., Kavoussi, L. R., Novick, A. C., et al. (eds.): Campbell-Walsh Urology, 10th Edition. Elsevier Saunders, Phiadelphia, 2012

[2] Magyar, P., Somoskövi, Á. (eds.): Pulmonary and extrapulmonary tuberculosis. [Pulmonalis és extrapulmonalis tuberculosis.] Medicina Könyvkiadó, Budapest, 2007. [Hungarian]
[3] Bakos, Á., Böszörményi, N. G., Csoma, Zs., et al.: Epidemiologic and operational data of the pulmonology network in 2014. [A pulmonológiai hálózat 2014. évi epidemiológiai és múködési adatai.] Korányi Bulletin, 2015, (1), 4-17. [Hungarian]

[4] Global tuberculosis report 2014. World Health Organization Press., Geneva, 2014.

[5] Mándy, Y.: Mycobacteria. In: Pál, T. (ed.): Textbook of medical microbiology. [Mycobaktériumok. In: Pál, T. (szerk.): Az orvosi mikrobiológia tankönyve.] Medicina Könyvkiadó, Budapest, 2012. [Hungarian]

[6] Cek, M., Lenk, S., Naber, K. G., et al., Members of the Urinary Tract Infection (UTI) Working Group of the European Association of Urology (EAU) Guidelines Office: EAU guidelines for the management of genitourinary tuberculosis. Eur. Urol., 2005, 48(3), 353-362.

[7] Huang, L. H., Wen, M. C., Hung, S. W., et al.: Renal tuberculosis presenting as a complicated renal cyst. Urology, 2012, 80(6), e69-e70.

[8] Matsumura, N., Yamamoto, K., Hirohashi, R., et al.: Renal tuberculosis mimicking hydronephrosis. Intern. Med., 2005, 44(7), 768 .

[9] Androulaki, A., Papathomas, T. G., Liapis, G., et al.: Inflammatory pseudotumor associated with Mycobacterium tuberculosis infection. Int. J. Infect. Dis., 2008, 12(6), 607-610.

[10] Izbudak-Oznur, I., Sözen, S., Işik, S.: Renal tuberculosis mimicking xanthogranulomatous pyelonephritis: ultrasonography, computed tomography and magnetic resonance imaging findings. Turk. J. Pediatr., 2002, 44(2), 168-171.

[11] Clifford, A. V., Noon, A. P., Raw, D., et al.: Renal calcified mass misdiagnosed as a renal calculus in an adult with tuberculosis "autonephrectomy": a case report. Cases J., 2009, 2, 7613.

[12] Bouziane, Z., Boukhabrine, K., Lablou, Z., et al.: Tuberculosis of the renal artery: a rare cause of renovascular arterial hypertension. Ann. Vasc. Surg., 2009, 23(6), 786.e7-e9.

[13] Simon, H. B., Weinstein, A. J., Pasternak, M. S., et al.: Genitourinary tuberculosis. Clinical features in a general hospital population. Am. J. Med., 1977, 63(3), 410-420.

[14] Gow, J. G., Barbosa, S.: Genitourinary tuberculosis. A study of 1117 cases over a period of 34 years. Br. J. Urol., 1984, 56(5), 449-455.

[15] Strausz, J.: Tuberculosis. [Tuberculosis.] Orv. Hetil., 2008, 149(34), 1610-1611. [Hungarian]

[16] Barnard, M., Albert, H., Coetzee, G., et al.: Rapid molecular screening for multidrug-resistant tuberculosis in a high-volume public health laboratory in South Africa. Am. J. Respir. Crit. Care Med., 2008, 177(7), 787-792.

[17] Bilen, C. Y., Inci, K., Erkan, I., et al.: The predictive value of purified protein derivative results on complications and prognosis in patients with bladder cancer treated with bacillus CalmetteGuerin. J. Urol., 2003, 169(5), 1702-1705.

[18] Krishnamoorthy, S., Gopalakrishnan, G.: Surgical management of renal tuberculosis. Indian J. Urol., 2008, 24(3), 369-375.

[19] Zhang, X., Zheng, T., Ma, X., et al.: Comparison of retroperitoneoscopic nephrectomy versus open approaches to nonfunctioning tuberculous kidneys: a report of 44 cases. J. Urol., 2005, 173(5), 1586-1589.

[20] Han, W. K., Park, Ү. H., Jeon, H. G., et al.: The feasibility of laparoendoscopic single-site nephrectomy: initial experience using home-made single-port device. Urology, 2010, 76(4), 862865 .

(Murányi Mihály dr., Debrecen, Nagyerdei krt. 98., 4032 e-mail: vezermurmillo@gmail.com) 